ISBN 978-93-86878-32-8

14th PARIS International Conference on Marketing, Economics, Education and Interdisciplinary

Studies (MEEIS-19)

Paris (France) Nov. 12-14, 2019

\title{
Technology and Economic Growth: a Comparative Analysis of South Korea and Turkey
}

\author{
Caglar Koc ${ }^{1}$ and Suat Teker ${ }^{2}$ \\ ${ }^{1}$ International Finance Corporation, World Bank, Wien, Austria. \\ ${ }^{2}$ Isik University, Istanbul, Turkey.
}

\begin{abstract}
This paper intends to put forward the historical perspectives of industrial revolutions and analyze the effects of revolutions on the quality of life. This research uses a review and analysis approach for the historical evolment of industrial revolutions in general. All industrial revolutions strongly affected the quality of life of people. However, the industry 4.0 has completely changed the way of living for every single party, e.g. businesses, governments, people. The new definition of internet-of-things looks to rule the new order of competitiveness in the World. The jobs have been recently created we never imagined ten years ago. Most jobs have started to disappear we never thought about. Technological innovation and advancement activities have a significant impact on international competitiveness.
\end{abstract}

Keywords: High technology, economic growth, innovation, industry revolutions, industry 4.0.

\section{Introduction}

The critical role of history here is to characterize the complexity of how revolutions change the world order. Arguably most important is the understanding of the dynamics of the revolutions that examine its historical developments can make it uniquely complicated, but it is valuable to create a roadmap. It is complicated as it contains education, science, manufacturing, capital intensity, technological advances/innovations, and efficiency. In order to understand the rapidly changing world, it will be extremely beneficial to recognize and discuss the ideas of Alvin Toffler. Toffler creates a framework which is starting from the first periods of the history up to the present day and draws attention to the benefit of the system understanding by making projections about the future. Human history has undergone three significant paradigm transitions, and these are described with the waves metaphor by a well-known sociologist and philosopher Alvin Toffler. Human history has undergone three significant paradigm transitions, and these are described with the waves metaphor by a well-known sociologist and philosopher Alvin Toffler; the agricultural revolution which is the first nascent point of the wave has emerged after the Neolithic period of human history. The humankind spent thousands of years in the first wave. The most critical transition event in the society of the agricultural period, the hunter-gatherer way of life was transferred to be a farmer (producer); therefore, the history of humanity was moved from pre-history to civilization. People have learned to live together. They discovered the advantages of living together. Along with their coexistence, the concept of property emerged, and the foundations of fundamental rules and laws were established. While spending a plenty amount of time in the First Wave, the rate of economic growth was unsatisfied for the development, and the range of inequality in the living standards was not swiftly widening in that period.

The second part of the wave which is described as an Industrial Revolution began around 1750s in England and spread to other countries in the European continent. The essence of the Industrial Revolution is examined as the phenomenon that made a remarkable effect on the manufacturing system. Economic development became very quick; national markets were created, new network systems was formed since technological developments were entirely implemented into the industries; steam power, railroads, electrification, and assembly line. So instead of insisting for a keeping paradigm approach, established a significant number of factory and industries, focused on scientific for doing efficient business models and inventions, social and cultural life moved from agricultural life to manufacturing life for rationalism, mechanization and mass production. The third extension 
arm is the "Internet Age" which is based on the knowledge power. In the information society, the number of employees in the information sector exceeded the number of employees in the industrial area, and the production of information and knowledge has become the essential element of creating value. It facilitated the transmission of knowledge, accelerated social change, and most importantly increased the impact of the change, so it has been causing various crises and pains for those who do not understand the requirement of this period. Toffler considered the development of societies so far in three main Wave Theory. All three of these waves have created new lifestyles or a new way of doing business models that would not come to mind even earlier generations (Toffler, 1981).

Technological developments that gained momentum after the Industrial Revolution became the most important driving force of the economy and growth. Countries that produce technology and use this technology most efficiently are at the forefront of the economic growth process, and the countries that do not catch the pace of technological development are left behind in this race. Therefore, it is essential to emphasize how the industry developed throughout history through technological developments.

\section{History of Industry Revolutions}

It is beneficial to examine the Industrial Revolution as it has contributed a vital capacity for economic developments. In fact, traditional production industries are the driving power of today's digital and artificial intelligence production system with the exponentially growing technologies. In order to emphasize the power of economic development and competitiveness and why countries and their manufacturing systems need to adapt or closely follow technological progress? In every period, the different type of technology inventions made an impact on the countries' economic improvement or declines. Technology development activities led to economic development by enhancing labor productivity, and new technologies enable each worker to contribute a more considerable number of outcomes and services.

- Industry Revolution 1.0; The invention of the James Watt's steam power representing clearly as an indicator or start point of Industry Revolution 1.0 in the world history, and it is the most well-known information about for this period.

- Industry Revolution 2.0; Henry Ford's assembly line triggered paradigm change in the history of the manufacturing process. The model $\mathrm{T}$ was the first automobile on the assembly line, thus producing less expensive cars to the world and creating higher wage jobs in the market.

- Industry Revolution 3.0; It is an entirely different period when computer technology used as an interface. In this period, the importance of human power diminished, and the speed of production increased considerably through computer systems.

Industry Revolution 4.0; Cyber-Physical-Systems is about the constant development of knowledge and information system in blending with an uncontrollable increase of computing, transmission, and storage capacity, it facilitates the evolution of frequently strong, interconnected new technological operations. This new capability, devices can communicate with several other machines and with the manufacturers to perform whatever people now describe as a "cyber-physical production system" (CPPS).

Technological innovation and advancement activities have a significant impact on international competitiveness. Developed countries mostly have high technology production activities; developing countries have been trying to accelerate their economic growth and development by adopting developed countries' technologies to increase their technology production capability or produce own product in the long run. In the second part of this paper intends to evaluate the impact of high technology of economic development on economic growth between Turkey and South Korea and shows whether is there a positive correlation between educational development and economic growth through empirical analysis. 


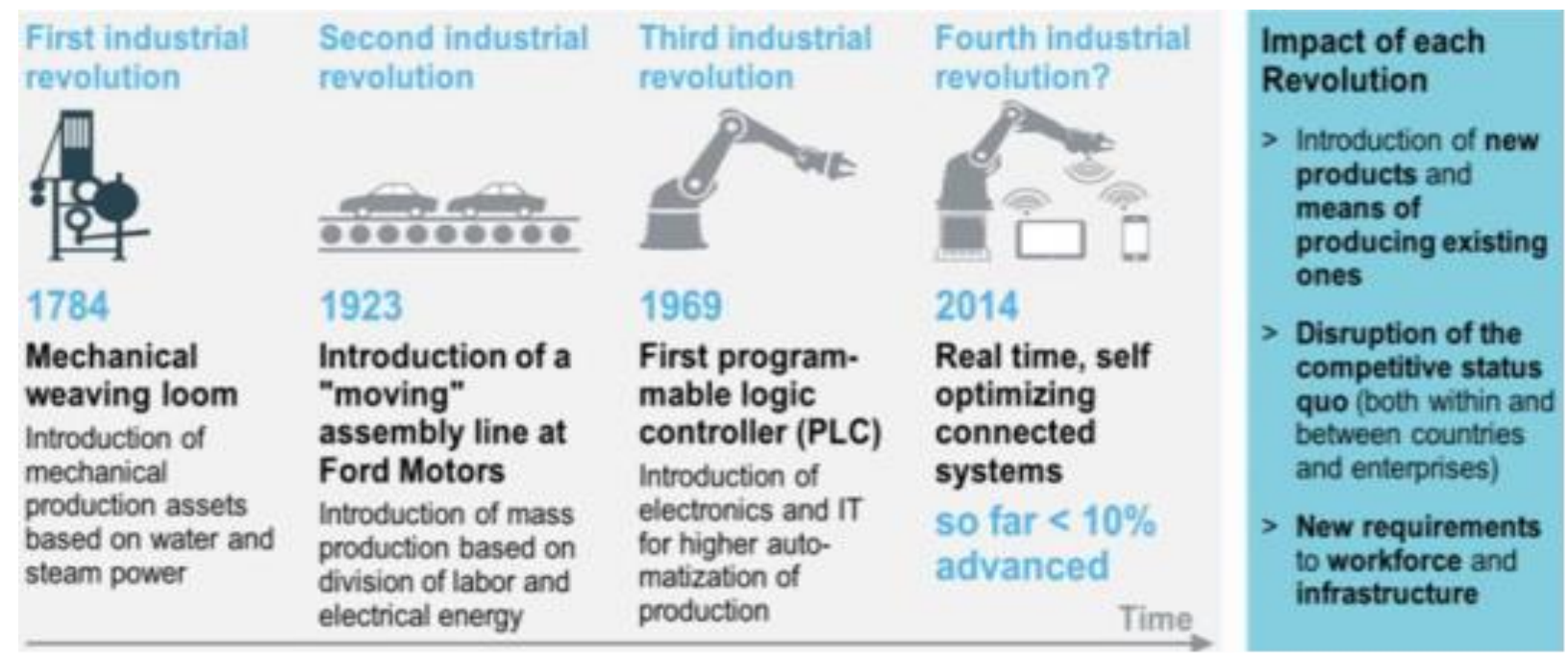

Fig. 1. Development Stages of Industrial Revolutions

\section{Economic Overlook for Turkey and South Korea}

Technology is an important indicator when evaluating the development level of countries. In order to develop and advance, it is necessary to have a technological infrastructure and to have a contemporary functioning structure of the infrastructure. In a globalizing world, technology is an essential competitive element. In this context, this part of the article is to analyze the macroeconomic performance of Turkey and South Korea in the period of 1960-2015 by using descriptive analysis method with the help of primary macroeconomic data provided by various international organizations. Countries that have similar economic structures at a particular time can reach completely different economic development levels as a result of their strategies and policies. Therefore, South Korea and Turkey could be the most convenient example in this context, when examining table 3.1 below it shows that in the Turkish economy per person income was three times bigger than South Korea, despite the have same amount of populations (Krueger, 1987).

Turkey has had a definite better position, and a more hopeful development possibility right before the 1960s. It is also important to highlight that the Turkish economy and developmental progress has been impressively increased through structural state policies between 1923 and 1950. It might be right but, today's world economic development outcomes have been showing a miracle growth for South Korea; the growth rates of GDP, production, and incomes per capita have reached unprecedented heights. Especially, Turkey and South Korea have had similar economic indicators in the 1960s which is the beginning of the comparative period, and South Korea has significantly and confidently separated from this economic circumstance after that period. Therefore, the Republic of Korea has been writing a spectacular economic success history since the 1960s. The success of Korean economic development and becoming fastest-growing achieved after the colonial period and despite the Korean War, military interventions and defense expenses (Chung, K. H., Lee, H. C. and Jung, K. H., 1997).

Table 1 presents background details on the economic similarities and additional cases which happened in Turkey and South Korea between the 1920s and 1950s. In the second section then trace the economic differentiation period $1960 \mathrm{~s}$ in two countries. A final part then contracts what the source of economic differentiation performance of the two countries is. In this regard, it is essential to draw attention to the outlook of the last year of both countries similarities era; among the 135 countries, 35 country's GDP Per capita was better than Turkey and 80 countries than South Korea. There were no significant differences between both countries in terms of sectoral distribution of production. As a matter of fact, that while both countries were mainly exporting agricultural and non-value-added products, Turkey owned their better position since their natural resources wealth had much better than South Korea in these years (Gunay, 2005).

The historical similarity analysis would be useful, in order to clearly understand where the starting point of effective differentiation was for both selected countries above - examined similar variables that caused influence on economic developments strategies and designated the significant consequence of different policy preference in the long run. The second part of the analysis gives an idea of some fundamental economic structure contrast of both countries in the mid-1960s. It would be better to start mentioning significant geographical difference before fundamental economic structure contrast: Turkey had more opportunities because of the 
climate conditions, underground wealth, tourism varieties, more extensive lands and the coast of Mediterranean, Aegean, Black Sea. On the other hand, the composition of South Korea is quite land scarce and unfavorable for agricultural life, therefore, right at the starting point of the differentiation year 1960, the most critical agriculture policy is neglected, and it is replaced by domestic food production policies in the 1970s (Krueger, 1987).

Table I. Similarities in Economic Developments for Turkey and South Korea

\begin{tabular}{|c|c|}
\hline $\begin{array}{l}\text { The last significant victory of the Ottoman troops was at } \\
\text { Gallipoli in } 1915 \text { under the direction of Ataturk, so Turkey } \\
\text { was in place of the Ottoman Empire until the first World } \\
\text { War. Moreover, then emerged as an independent new } \\
\text { country under the leadership of Ataturk in } 1923 \text {. }\end{array}$ & $\begin{array}{l}\text { The Japanese occupation control of Korea 1910-1945, there was a } \\
\text { worldwide race for colonists performances among the primary } \\
\text { hegemonic countries because each empire or nations tried to } \\
\text { increase fields of authority for their economy and continued } \\
\text { colonial objectives. }\end{array}$ \\
\hline $\begin{array}{l}\text { In the } 1920 \text { s and } 1930 \text { s, many governmental institutions that } \\
\text { would be important in the postwar years, most of them were } \\
\text { established. Mainly, "etatism" played a vital role in this } \\
\text { period. }\end{array}$ & $\begin{array}{l}\text { During the } 1920 \text { s and } 1930 \text { s, considerable manufacturing activity } \\
\text { developed in Korea under the Japanese occupation with technical } \\
\text { human resources. }\end{array}$ \\
\hline $\begin{array}{l}\text { Turkey found itself confronts a challenge as it is located in } \\
\text { the middle of two different regions; Europe and the Middle } \\
\text { East. }\end{array}$ & $\begin{array}{l}\text { South Korea is located between the two geographic giants of China } \\
\text { and Japan, and these are giants of East Asia. }\end{array}$ \\
\hline $\begin{array}{l}\text { During the Second War, Turkey was not an active player, but } \\
\text { their inflation rates reached incredible rates due to the } \\
\text { undesirable developments in international markets; the } \\
\text { economy was utterly stagnant. }\end{array}$ & $\begin{array}{l}\text { Second World War had a direct impact on the history of South } \\
\text { Korea, the Japanese colonial powers left, and the country } \\
\text { partitioned. The South of Korea started its journey with } 17 \text { million } \\
\text { people with deplorable economic conditions. }\end{array}$ \\
\hline $\begin{array}{l}\text { After the war, Turkey received aid from the United States } \\
\text { under the Point Four Program, and Marshall Plans to } \\
\text { development of infrastructure and agricultural conditions. }\end{array}$ & $\begin{array}{l}\text { Due to the direct outcomes of war, South Korea received quite } \\
\text { sizable amounts of foreign aid from the United States against } \\
\text { hyperinflation problem. }\end{array}$ \\
\hline $\begin{array}{l}\text { Turkey entered a new period with the election which is held } \\
\text { in } 1950 \text {. The single part rule ended in the country with } \\
\text { Republican People's Party period. }\end{array}$ & $\begin{array}{l}\text { Almost the same period, The Republic of Korea entered a new } \\
\text { political era with President Seugman Rhee in } 1948 \text {, and he stayed } \\
\text { the office until } 1960 .\end{array}$ \\
\hline $\begin{array}{l}\text { The military intervention happened in } 1960 \text { and sponsored } \\
\text { the writing of a new constitution which stated effectively in } \\
\text { 1961, and a civilian government returned the political life } \\
\text { after the election was held in the country. }\end{array}$ & $\begin{array}{l}\text { A student revolution emerged in South Korea in 1960, it also } \\
\text { widespread to other groups and it caused the resignation of Rhee. } \\
\text { Due to the big chaos in the country, it brought a military coup. } \\
\text { General Park Chung Hee was chairman of a military council, and } \\
\text { then he was elected as President with the } 1963 \text { s election. }\end{array}$ \\
\hline
\end{tabular}

In Table 2, the characteristic data of Turkey and South Korea are used to compare economic growth. Most of the data were obtained from World Bank Data resources. The time interval was used between 1960 and 2017, in order to show the differentiation of Industrial Revolutions differentiation, 1970 - 1980 End of the Industrial Revolution 2.0, 1980 - 2010 Industrial Revolution 3.0 and 2010 - ongoing Industrial Revolution 4.0. Also, Table 2 give us descriptive information about how do countries' well-structured and up to date strategies lead to economic development? In order to show the positive correlation between these variables, it would be better to start with the examination of the selected countries economic developments

Table II. Differences in Economic Outlook for Turkey and South Korea

\begin{tabular}{|l|l|}
\hline S. Korea / First $\mathbf{5}$ Year Plan 1962 - 1966 & Turkey / First 5 Year Plan 1963 - 1967 \\
\hline Develop coal energy production & Importance of basic infrastructure investments \\
\hline Highlight attention on the infrastructure developments & Support the private sector for employment problem \\
\hline Improve agricultural potency & Increase the level of living standards \\
\hline Establishment of the Korea Institute of Science and Technology & $\begin{array}{l}\text { Establishment of The Science and Technological Research } \\
\text { Council }\end{array}$ \\
\hline GDP (million): 2.813 to 3.928 & GDP (million): 10.355 to 15.660 \\
\hline GDP Per capita: 106 to 133 & GDP Per capita: 351 to 482 \\
\hline Second 5 Plan $1967-1971$ & Second 5 Year Plan $1968-1972$ \\
\hline Korea Institute of Science and Technology & The economic activities of the private sector are planned \\
\hline
\end{tabular}




\begin{tabular}{|c|c|}
\hline & indirectly. \\
\hline Focus requirements of heavy industry & $\begin{array}{l}\text { The primary objective is to reach the determined GDP growth } \\
\text { rates. }\end{array}$ \\
\hline Build significant roadways for better transportation & Reorganization of KIT (state-controlled entities) \\
\hline Discover food self-support & Harrod Domar type growth model is accepted \\
\hline Greenification works for eco-friendly life & Attempted to reduce the inequality of regional development rate. \\
\hline GDP (million): 4.854 to 9.889 & GDP (million): 17.500 to 20.431 \\
\hline GDP Per capita: 161 to 301 & GDP Per capita: 526 to 558 \\
\hline Third 5 Year Plan 1972 - 1966 & Third 5 Year Plan 1973 - 1977 \\
\hline Structured "Heavy Chemical Industrialization Plan" & Targeted to reduce dependence on external funds \\
\hline Significant attention to funding the HCIP & Increased the importance of higher education institutions \\
\hline Research Institute established - Daeduk Innopolis & $\begin{array}{l}\text { Increased attention on inequalities in the distribution of course } \\
\text { materials }\end{array}$ \\
\hline $\begin{array}{l}\text { Seek significant funds from foreign countries or international } \\
\text { organizations }\end{array}$ & A complete transformation of the education system was aimed \\
\hline GDP (million): 10.842 to 38.265 & GDP (million): 25.724 to 58.676 \\
\hline GDP Per capita: 324 to 1051 & GDP Per capita: 686 to 1427 \\
\hline Fourth 5 Year Plan 1977 - 1981 & Fourth 5 Year Plan 1979 - 1983 \\
\hline Give autonomy to the private sector & A detailed evaluation of all sectors and new policies \\
\hline Increase the level of social equality & Condensation on balance of payments \\
\hline Korea Advanced Institute of Science and Technology & To raise the standard of health services \\
\hline Support technological advancements and industrial performance & Reduction of unemployment through new measures and projects \\
\hline GDP (million): 38.265 to 72.425 & GDP (million): 89.394 to 61.678 \\
\hline GDP Per capita: 1051 to 1870 & GDP Per capita:2079 to 1310 \\
\hline Fifth 5 Year Plan 1982 - 1986 & Fifth 5 Year Plan 1985 - 1989 \\
\hline Increase the importance of efficiency & $\begin{array}{l}\text { Dissemination of preventive health services throughout the } \\
\text { country }\end{array}$ \\
\hline The National R\&D Program & $\begin{array}{l}\text { Increasing the tendency to save and obtaining investments from } \\
\text { internal sources }\end{array}$ \\
\hline Support Chaebols (small- and medium-sized firms) & Improve quality at all levels of the education system \\
\hline Support the open market economy & $\begin{array}{l}\text { The relations with the European Economic Community will be } \\
\text { re-organized }\end{array}$ \\
\hline GDP (million): 77.783 to 115.537 & GDP (million): 67.234 to 107.143 \\
\hline GDP Per capita: 1978 to 2803 & GDP Per capita: 1368 to 2022 \\
\hline Sixth 5 Year Plan 1987 - 1991 & Sixth 5 Year Plan 1990 - 1994 \\
\hline Establish order in the economy for increasing free market & To partially reduce an inflation \\
\hline Accelerate import liberalization & Give more importance to social policies \\
\hline Increased R\&D investment from 2.4 of the GNP to over 3 percent & $\begin{array}{l}\text { Increase the financing resource options for the realization of } \\
\text { private sector investments }\end{array}$ \\
\hline The balance of income distribution for social equality & $\begin{array}{l}\text { Qualified human resources planning to respond to the } \\
\text { requirements of manufacturing }\end{array}$ \\
\hline GDP (million): 146.133 to 325.734 & GDP (million): 150.676 to 130.690 \\
\hline GDP Per capita: 3511 to 7523 & GDP Per capita: 2794 to 2270 \\
\hline Seventh 5 Year Plan 1992 - 1996 & Seventh 5 Year Plan 1996 - 2000 \\
\hline Improve the global competitiveness of Korean global companies & $\begin{array}{l}\text { The focus of science and technology policy, raising the level of } \\
\text { knowledge of society }\end{array}$ \\
\hline Develop social equity and balanced development & $\begin{array}{l}\text { Redefining the role of the state to increase efficiency in public } \\
\text { services }\end{array}$ \\
\hline Support internationalization - branding & $\begin{array}{l}\text { Improvement of public finance, rationalization of the financial } \\
\text { system }\end{array}$ \\
\hline Build a foundation for the unification of Korea & Reforms were determined to strengthen the competitive \\
\hline
\end{tabular}




\begin{tabular}{|l|l|}
\hline & environment \\
\hline GDP (million): 350.051 to 598.095 & GDP (million): 181.475 to 272.979 \\
\hline GDP Per capita: 8002 to 13138 & GDP Per capita: 3054 to 4317 \\
\hline
\end{tabular}

\section{Conclusion}

This article intended to examine how education investment caused economic development through under the subject of high technology. Both countries' governmental education investments acknowledge the number of essential impacts that education has on economic development and welfare, also some remarkable problems which needed to be addressed the requirements of Industry Revolution 4.0. However, education and technology are mostly matters in this context because it appears to represent an obvious success of economic developments. Either way, the fact that both developed and developing countries education approaches are looking at the same solvable problems is surely progress.

It is useful to re-point out that this point; education and technology are mostly matters in this context because technology orientation appears to represent an apparent success of economic developments. Either way, the fact that both the developed and developing countries' education approaches are looking at the same solvable problems is undoubtedly progress. Therefore, Turkey should take necessary steps about education. Otherwise, Turkey will continue to cement its reputation which is called as the "fragile economy".

\section{References}

[1] Barkey, H. J. (1990). The State and the Industrialization Crisis in Turkey. Boulder: Westview Press.

[2] Chung, K. H., Lee, H. C. and Jung, K. H. (1997). Korean Management: Global Strategy and Cultural Transformation. New York: Walter de Gruyter.

https://doi.org/10.1515/9783110816112

[3] Eğilmez, M. (2018). Değişim Sürecinde Türkiye. Istanbul: Remzi Kitabevi.W. D. Doyle, "Magnetization reversal in films with biaxial anisotropy," in Proc. 1987 INTERMAG Conf., 1987, pp. 2-6. (Published Conference Proceedings style)

[4] Gunay, C. (2005). Türkiye ve Güney Kore’de Uzun Dönemli Büyüme;Karşılaştırmalı Bir Analiz(1960-1980). Çukurova Üniversitesi, Adana, 14 - 16.

[5] Joonghae Suh, Chen, Derek H. C. (2007). Korea as a Knowledge Economy : Evolutionary Process and Lessons Learned. Washington, DC: World Bank: WBI Development Studies

[6] Krueger, A. (1987). The Importance of Economic Policy in Development: Contrasts Between Korea and Turkey. Cambridge: NBER, Working Paper Series, No: 2195.Transmission Systems for Communications, $3^{\text {rd }}$ ed., Western Electric Co., Winston-Salem, NC, 1985, pp. 44-60. (Handbook style)

https://doi.org/10.3386/w2195

[7] Özdemir, Y. (2015). Turkey's Justice and Development Party: An Utmost Case of Neoliberal Populism. Montreal: The ECPR's General Conference.

[8] Toffler, A. (1981). The Third Wave. London: Pan Books Ltd 